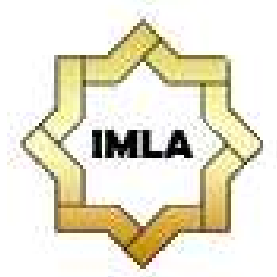

Al-Ta'rib
Jurnal Ilmiah Program Studi Pendidikan Bahasa Arab
IAIN Palangka Raya
Vol. 9, No. 2, December 2021, 145-154
p-ISSN 2354-5887 | e-ISSN 2655-5867
DOI: https://doi.org/10.23971/altarib.v9i2.3263

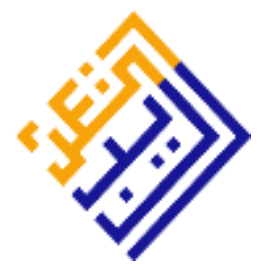

\title{
TEACHER'S PERSONALITY AS A MOTIVATION IN ARABIC LEARNING: A SYSTEMATIC REVIEW BASED ON FIVE PROFESSIONAL TEACHER PERSONALITY FRAMEWORKS
}

\author{
Adela Anggaraini' ${ }^{1}$, Sutaman ${ }^{2}$, Abdul Muntaqim al Anshory ${ }^{3}$ \\ 1,2,3 Universitas Islam Negeri Maulana Malik Ibrahim Malang, Indonesia \\ E-mail: adelanggraini85@gmail.com
}

\begin{abstract}
Studies on the factors that influence students' enthusiasm for learning Arabic are still focused on the strategies and media used. Therefore, this paper presents a systematic study of various educator personalities that can motivate students to learn Arabic. This research used a literature study approach. The articles were selected using the Preferred Reporting Items for Systematic Reviews and Meta-Analysis (PRISMA) approach and were analyzed using a framework of five professional teacher personalities. In the results of this study, several essential findings were described: (1) a steady and stable personality is manifested by the conformity of the attitude of Arabic educators to the prevailing norms, (2) mature personality is implemented in a positive enthusiasm of learning interaction between educators and students, (3) an educator's prudent and wise personality in the Arabic learning process is implemented in the form of neutrality or equitable behavior towards all students, (4) an authoritative and polite personality is actualized in a comfortable and positive atmosphere when the Arabic learning process occurs, and (5) a noble character is manifested by the educator's example who in his daily life is always active in using Arabic so that it affects the motivation of students to be active in speaking Arabic.
\end{abstract}

Keywords: Teacher Personality, Learning Arabic Motivation, Professional Teacher

\section{Abstrak}

Dalam pembelajaran bahasa Arab, kajian tentang faktor-faktor yang mempengaruhi peserta didik untuk semangat belajar bahasa Arab masih terfokus pada efektifitas penggunaan strategi maupun media yang digunakan. Maka dari itu, tulisan ini menyajikan kajian sistematis tentang macam-macam kepribadian pendidik yang dapat memotivasi belajar bahasa Arab bagi peserta didik. Penelitian ini menggunakan pendekatan studi pustaka. Adapun artikel-artikel yang dipilih menggunakan pendekatan Preferred Reporting Items for Systematic Reviews and Meta-Analysis (PRISMA) dan dianalisis menggunakan kerangka lima kepribadian guru profesional. Dari hasil penelitian ini, peneliti menjabarkan beberapa temuan penting yakni: (1) kepribadian mantap dan stabil diwujudkan dengan kesesuaian sikap pendidik bahasa Arab terhadap norma yang berlaku. (2) kepribadian dewasa diimplementasikan dengan bentuk semangat positif dari interaksi belajar antara 
pendidik dengan peserta didik. (3) Kepribadian arif dan bijaksana seorang pendidik dalam proses pembelajaran bahasa Arab diimplementasikan dengan bentuk netralitas atau berperilaku adil terhadap semua peserta didik. (4) Kepribadian wibawa dan santun diwujudkan dengan suasana nyaman dan positif ketika proses pembelajaran bahasa Arab berlangsung. (5) Kepribadian berakhlak mulia diwujudkan dengan keteladanan dari seorang pendidik yang dalam kesehariannya selalu aktif menggunakan bahasa Arab sehingga mempengaruhi motivasi peserta didik untuk aktif dalam berbicara bahasa Arab.

Kata kunci: Kepribadian Guru, Motivasi Belajar Bahasa Arab, Guru Profesional

\section{INTRODUCTION}

The teacher's personality in the learning process is one of the important factors in achieving language learning success. The positive atmosphere resulting from the teacher's personality can encourage students to participate in foreign language learning (FLE)(Ahmadi-Azad et al., 2020).

On the other hand, in his research, Zhang reports that the teacher's personality greatly influences the teaching style performed by the teacher (Zhang, 2007). The ideal teacher personality among students can provide great learning satisfaction results, especially in emotional stability and awareness (Kim \& MacCann, 2016). The characteristics of the teacher's personality have a positive relationship with teaching techniques (Bramwell et al., 2011; Chan \& Yuen, 2014). It certainly has implications for students' learning motivation, considering that it is crucial in achieving learning outcomes (Bower, 2019; de Burgh-Hirabe, 2019; Escobar Fandiño \& Silva Velandia 2020; Mubarak et al., 2021).

In learning Arabic, previous research that examines the effect of the teacher's personality, specifically on the five personality frameworks to increase students' motivation in learning Arabic, is currently still limited. Researches on the elements of motivation to learn Arabic still lead to the aspect of using interactive learning media (Albantani, 2019; Arifin et al., 2021; Ilmiani et al., 2020) or ideal strategies used by teachers to support Arabic learning outcomes (Aburezeq, 2020; Mubarak et al., 2020). Therefore, this systematic study aims to overview the effects of the five teacher personality frameworks in increasing students' motivation to learn Arabic.

The study results expect a contribution to the personality selectivity aspect of ideal teacher and lecturer candidates in learning Arabic.

\section{METHOD}

The researcher used a literature study approach. First, the researcher searched for articles on the topic of the personality of the Arabic language teacher using national and international databases. The researcher also determined one main criterion in selecting articles: the articles were published within the last ten years (2011-2021). In that period, it is expected that the content of the article is still relevant.

Second, the selection of articles for review used the Preferred Reporting Items for Systematic Reviews and Meta-Analysis (PRISMA) guidelines, which included: (1) defining topics and criteria, (2) determining sources of information, 
(3) selecting relevant literature, (4) collecting articles and (5) analyzing articles (Page et al., 2021).

\section{Chart 1.}

\section{PRISMA Flowchart for Article Selection}

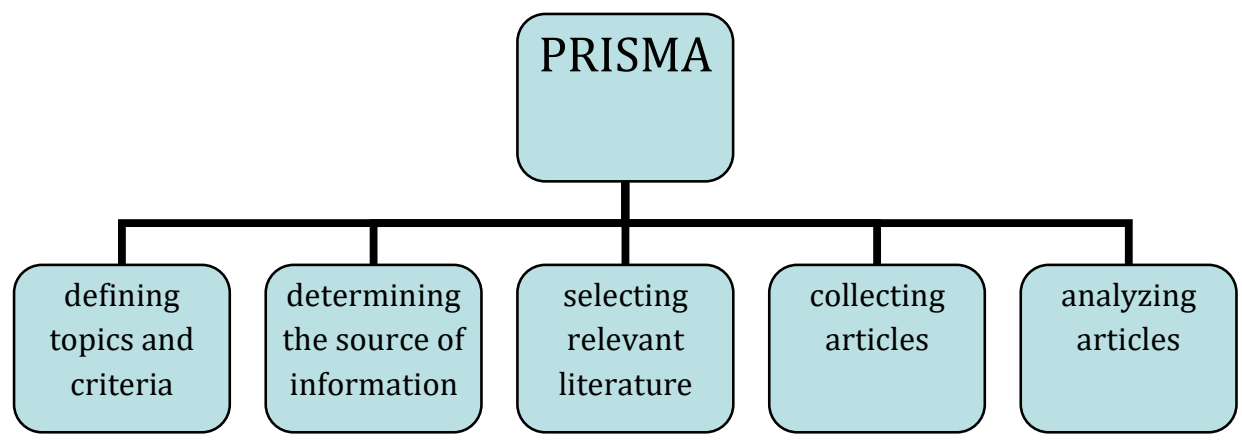

Third, the research findings were analyzed using a framework of 5 professional teacher personalities, such as steady and stable personality, mature personality, prudent and wise personality, authoritative and polite personality, and noble character (Undang-Undang Nomor 14 Tahun 2005, n.d.). Therefore, the research results would be arranged thematically according to the points in the five professional teacher personality frameworks mentioned above.

\section{RESULT AND DISCUSSION \\ Steady and Stable Personality}

The first teacher personality competency framework is that the teacher must have a steady and stable personality. Isop, Maryani, and Selvi (2020) correlate the relationship between the personality competencies of Arabic teachers and student learning outcomes. The personality of the Arabic language teacher correlates with student learning outcomes with a significant value of 0.02 . They also suggest that Arabic teachers should have a steady and stable personality to increase students' motivation to learn Arabic (Syafe'i \& Maryani, 2020).

Syarifuddin (2014) also emphasizes that a steady and stable personality must be embedded in Arabic teachers to develop professional abilities (Syarifuddin, 2014). It, of course, has implications for the normativity of a teacher when the learning process occurs so as not to do anything outside of religious, legal, and social norms.

It can be concluded from the articles above that a steady and stable personality for Arabic language educators can be manifested by conforming to the attitudes of educators towards the applicable norms, such as the aspects of religious norms, legal norms, and social norms. Acting according to norms indicates a person's personality that is steady and stable, as described in the Act (Undang-Undang Nomor 14 Tahun 2005, n.d.). It also has a positive impact on students' learning motivation as it is reported by Rahayu (2019) that a steady and stable personality in an educator has implications for students' learning motivation. (Rahayu, 2019). A steady and stable personality raises the enthusiasm and willingness of students to learn, regulates teaching and learning processes and 
situations humanely, and transfers the influence of learning in school to its application in life outside school (Fitriana, 2019).

\section{Mature Personality}

In one of the teacher's personality competency frameworks, it is expressed that the teacher must have a mature personality. Hendra (2021) reports that in learning Arabic, educators should have an upbeat enthusiasm. It is proven by the energetic and fun learning interaction atmosphere that the teacher applies so that the students easily understand the explanations given by the teacher. Good interactions foster a positive spirit and provide a sense of security and comfort in the Arabic learning process (Hendra, 2021).

Kassim, Damit \& Taat (2017) also report that the upbeat enthusiasm initiated by the teacher in the Arabic learning process positively influences students' learning motivation. The positive spirit that appears can minimize students' indolent and indifferent attitude in participating in the Arabic learning process (Kassim et al., 2017).

Based on Law number 14 of 2005, one indicator of a mature personality is an educator ethos that reflects a diligent and hardworking attitude with enthusiasm (energetic) in carrying out their duties (Undang-Undang Nomor 14 Tahun 2005, n.d.). Therefore, it comes to the conclusion that the mature personality that Arabic language educators can implement is a positive spirit implemented in learning interactions between educators and students. It is aligned with the results of Nakata, Nitta \& Studa's (2020) research which reported that positive interactions between educators and students in the learning process became a motivating factor for students in learning. (Nakata et al., 2020).

\section{Prudent and Wise Personality}

Prudent and wise personality is also one of the focuses of the findings in this study and is also one of the five teacher personality frameworks. Islam (2015) reports that one of the demotivating factors for students learning Arabic is the teacher's injustice in treating Arabic class students. The teacher prioritizes students who already have the basic Arabic language before, causing an attitude of "favoritism" in giving assignments and assessing the results. (Islam, 2015).

On the other hand, Hendra (2021) reports that an Arabic language educator must be neutral. Educators' neutrality towards students in the Arabic learning process is proven by not discriminating between students. Educators must act as people who can mediate gaps to students (Hendra, 2021).

From the analysis results above, it can be inferred that an educator's prudent and wise personality in the Arabic learning process is implemented in the form of neutrality or equitable behavior towards all students. The law explains that equitable treatment is one of the characteristics of a teacher who has prudent and wise competence (Undang-Undang Nomor 14 Tahun 2005, n.d.). In the learning process, the teacher must be fair in treating students, so it does not bring up the dominant student criteria in the class and potentially emerge the term "favoritism." Arlin (1999) reveals that a wise teacher becomes a model or characteristic of a developing teaching system (Arlin, 1999).

\section{Authoritative and Polite Personality}

Said, Fatmawati, and Masnan (2021) report that teachers must have an authoritative and disciplined personal quality standard according to their analysis 
of Arabic teachers' social competence to increase students' interest in learning. In this case, the Arabic teacher must make decisions independently on matters relating to the Arabic learning process. They also add that the importance of a teacher having a polite personality can help to direct Arabic students to have social intelligence that can be applied in daily life (Said et al., 2021).

Another study, conducted by Muslim, Ismail, Ghani, Nawawi, Rohman, \& Rostam (2020) on the quality traits of Arabic teachers agreed upon by students and teachers in Malaysia shows that an authoritative teacher belongs to the category of qualified teacher personality. The characteristic of a good relationship for qualified teachers is having a polite personality (Al-Muslim et al., 2020).

From the results of the article analysis above, it can be deduced that an authoritative and polite Arabic educator becomes one of the criteria for an educator that students expect. Educators who are polite in interacting with students have implications for a comfortable and positive atmosphere when the learning process occurs since feeling safe and comfortable when studying certainly affects their learning motivation (Mubarak et al., 2021).

\section{Noble Personality}

One of the teacher's personality frameworks is a noble character. The influence of noble character to motivate students' enthusiasm for learning Arabic generally tends to be seen in the Islamic boarding school culture.

The profile of a Kyai (Mudirul Ma'had), a role model for the students at Islamic boarding schools, is certainly gives a positive value to students' learning motivation in Arabic. It is attested by the results of Masnun's research (2020), which reports that Habib Hasan bin Ahmad Baharun, the Founder of Darullughah Wadda'wah Islamic Boarding School, revives the Arabic-speaking environment by consistently communicating using Arabic within the boarding school extended family environment. He even compiled several Arabic books which became the main reference for students to apply Arabic in daily life, such as Al-Muhawah AlHaditsah, Majmu'at Ashriyyah, and Kalimaat Al-Af'al wa Al-Asmaa' Al-Yawmiyyah (Masnun, 2020). According to Mahfuz's research (2017), these books are compiled based on the personal experiences of Habib Hasan bin Ahmad Baharun in everyday life (Mubarak, 2017).

It can be understood that from the analysis above, the exemplary noble character has been proven to impact students' motivation to learn Arabic positively. It also corresponds with the results of research by Hamdun (2016) and Nulaila, Muassomah, \& Abidin (2021) that the example of a teacher plays an essential role in students' motivation, especially in the aspect of language learning. (Hamdun, 2016; Nurlaila et al., 2021).

\section{CONCLUSION}

This systematic analysis provides information for Arabic language educators, especially on personality competencies that can foster students' motivation to learn Arabic. The analysis results generate several important findings: first, a steady and stable personality can be manifested by conforming to educators' attitudes towards the applicable norms, such as the aspects of religious norms, legal norms, and social norms. Second, the mature personality can be implemented in a positive enthusiasm of learning interactions between educators and students. 
Third, an educator's prudent and wise personality in the Arabic language learning process can be implemented in neutrality or equitable behavior towards all students. Fourth, an authoritative and polite personality can be actualized in a comfortable and positive atmosphere when the Arabic language learning process occurs. Fifth, the noble character is manifested by the educator's example, who is always active in using Arabic in his daily life, which affects the motivation of students to be active in speaking Arabic.

\section{REFERENCE}

Aburezeq, I. M. (2020). The Impact of Flipped Classroom on Developing Arabic Speaking Skills. The Asia-Pacific Education Researcher, 29(4), 295-306. https://doi.org/10.1007/s40299-019-00483-z

Ahmadi-Azad, S., Asadollahfam, H., \& Zoghi, M. (2020). Effects of teacher's personality traits on EFL learners' foreign language enjoyment. System, 95, 102369. https://doi.org/10.1016/j.system.2020.102369

Albantani, A. M. (2019). Social Media as Alternative Media for Arabic Teaching in Digital Era. ALSINATUNA, 4(2), 148-161. https://doi.org/10.28918/alsinatuna.v4i2.2043

Al-Muslim, M., Ismail, M. F., Ghani, S. A., Nawawi, Z., Rahman, M. A., \& Rostam, M. N. (2020). What are the Features of Quality for Arabic Teachers Agreed by Students and Teachers? Journal of Education and E-Learning Research, 7(1), 56-63. https://doi.org/10.20448/journal.509.2020.71.56.63

Arifin, Z., Febriani, S. R., \& Anasruddin, A. (2021). Using Bloom's Taxonomy in Arabic Learning Media to Elevate Student's Writing in Covid-19 Situation. Al-Ta'rib: Jurnal Ilmiah Program Studi Pendidikan Bahasa Arab IAIN Palangka Raya, 9(1), 1-12. https://doi.org/10.23971/altarib.v9i1.2530

Arlin, P. K. (1999). The wise teacher: A developmental model of teaching. Theory Into Practice, 38(1), 12-17. https://doi.org/10.1080/00405849909543825

Bower, K. (2019). Explaining motivation in language learning: A framework for evaluation and research. The Language Learning Journal, 47(5), 558-574. https://doi.org/10.1080/09571736.2017.1321035

Bramwell, G., Reilly, R. C., Lilly, F. R., Kronish, N., \& Chennabathni, R. (2011). Creative Teachers. Roeper Review, 33(4), 228-238. https://doi.org/10.1080/02783193.2011.603111

Chan, S., \& Yuen, M. (2014). Personal and environmental factors affecting teachers' creativity-fostering practices in Hong Kong. Thinking Skills and Creativity, 12, 69-77. https://doi.org/10.1016/j.tsc.2014.02.003

de Burgh-Hirabe, R. (2019). Motivation to learn Japanese as a foreign language in an English speaking country: An exploratory case study in New Zealand. System, 80, 95-106. https://doi.org/10.1016/j.system.2018.11.001 
Escobar Fandiño, F. G., \& Silva Velandia, A. J. (2020). How an online tutor motivates E-learning English. Heliyon, 6(8), e04630. https://doi.org/10.1016/j.heliyon.2020.e04630

Fitriana, S. (2019). Konsep Kepribadian Guru Menurut Zakiah Daradjat. Muslim Heritage, 4(2), Article 2. https://doi.org/10.21154/muslimheritage.v4i2.1798

Hamdun, D. (2016). Pembelajaran Bahasa Arab Berbasis Karakter di Sekolah Dasar. FENOMENA, 8(1). https://doi.org/10.21093/fj.v8i1.304

Hendra, F. (2021). Pengembangan Metodologi Pengajaran dan Kompetensi Kepribadian Dosen Bahasa Arab. Arabi : Journal of Arabic Studies, 6(1), 7992. https://doi.org/10.24865/ajas.v6i1.363

Ilmiani, A. M., Ahmadi, A., Rahman, N. F., \& Rahmah, Y. (2020). Multimedia Interaktif untuk Mengatasi Problematika Pembelajaran Bahasa Arab. AlTa'rib : Jurnal Ilmiah Program Studi Pendidikan Bahasa Arab IAIN Palangka Raya, 8(1), 17-32. https://doi.org/10.23971/altarib.v8i1.1902

Islam, A. M. S. (2015). Faktor Demotivasi Pembelajaran Bahasa Arab dalam Perspektif Siswa Madrasah. Arabiyat: Jurnal Pendidikan Bahasa Arab dan Kebahasaaraban, 2(1), 1-16. https://doi.org/10.15408/a.v2i1.1511

Kassim, N., Damit, D. S. A., \& Taat, D. M. S. (2017). Pengaruh Sikap Pelajar dan Pengajaran Guru terhadap Penguasaan Bahasa Arab dalam Kalangan Pelajar PPIB, UMS. Jurnal 'Ulwan, 2(1), 125-142.

Kim, L. E., \& MacCann, C. (2016). What is students' ideal university instructor personality? An investigation of absolute and relative personality preferences. Personality and Individual Differences, 102, 190-203. https://doi.org/10.1016/j.paid.2016.06.068

Masnun, M. (2020). Juhudu al-Habib Hasan Bin Ahmad Baharun Fiy Ta'limi Maharoh al-Kalam Bima'had Dar al-Lughah Wa al-Da'wah Bangil Pasuruan. Lughawiyyat: Jurnal Pendidikan Bahasa Dan Sastra Arab, 3(2), 113-139. https://doi.org/10.38073/lughawiyyat.v3i2.230

Mubarak, M. R. (2017). تعلبم مهارة الكلام على ضوء الدذخل الاجتماعي في معرد دار اللغة والدعوة باسوروان جاوى الثرقية Ibrahim]. http://etheses.uin-malang.ac.id/9753/

Mubarak, M. R., Ahmadi, A., \& Audina, N. A. (2020). Kombinasi Strategi Bernyanyi dan Bermain: Upaya dalam Menumbuhkan Motivasi Mahasiswa Tadris Biologi (TBG) dalam Pembelajaran Bahasa Arab. ALSUNIYAT: Jurnal Penelitian Bahasa, Sastra, dan Budaya Arab, 3(1), 15-31. https://doi.org/10.17509/alsuniyat.v3i1.23996

Mubarak, M. R., Audina, N. A., Wahdah, N., Hamidah, H., \& Ilmiani, A. M. (2021). Factors Influencing Motivation in Online Arabic Learning of Indonesian Older Man. Izdihar: Journal of Arabic Language Teaching, Linguistics, and Literature, 4(1), 15-26. https://doi.org/10.22219/jiz.v4i1.15270 
Nakata, Y., Nitta, R., \& Tsuda, A. (2020). Understanding motivation and classroom modes of regulation in collaborative learning: An exploratory study. Innovation in Language Learning and Teaching, $0(0), 1-15$. https://doi.org/10.1080/17501229.2020.1846040

Nurlaila, N., Muassomah, M., \& Abidin, M. (2021). Analysis of Moral Values in The Standards of the Ministry of National Education Perspective in the Process of Teaching the Arabic Language in Indonesia | Tahlil Al-Qiyam AlAkhlāqīyah 'Ala Dhou' Ma'āyīr Wizārah At-Tarbīyah Al-Wathanīyah fī 'Amalīyah Ta'līm Al-Lughah Al-'Arābīyah fī Indūnīsīyā. Al-Ta'rib: Jurnal Ilmiah Program Studi Pendidikan Bahasa Arab IAIN Palangka Raya, 9(1), 111-128. https://doi.org/10.23971/altarib.v9i1.2339

Page, M. J., Moher, D., Bossuyt, P. M., Boutron, I., Hoffmann, T. C., Mulrow, C. D., Shamseer, L., Tetzlaff, J. M., Akl, E. A., Brennan, S. E., Chou, R., Glanville, J., Grimshaw, J. M., Hróbjartsson, A., Lalu, M. M., Li, T., Loder, E. W., MayoWilson, E., McDonald, S., ... McKenzie, J. E. (2021). PRISMA 2020 explanation and elaboration: Updated guidance and exemplars for reporting systematic reviews. $B M J$, n160. https://doi.org/10.1136/bmj.n160

Rahayu, S. A. P. (2019). Peran Kepribadian Guru dalam Memotivasi Belajar Siswa. Vicratina: Jurnal Pendidikan Islam, 4(1), 54-74. https://doi.org/Peran Kepribadian Guru dalam Memotivasi Belajar Siswa

Said, S., Fatmawati, F., \& Masnan, S. (2021). Analisis Kompetensi Sosial Guru Bahasa Arab Dalam Meningkatkan Minat Belajar Siswa Bahasa Arab Pada Masa Pandemi Covid-19 Di Sma Muhammadiyah 1 Unismuh Makassar. AlMaraji' : Jurnal Pendidikan Bahasa Arab, 5(1), 1-17.

Syafe'i, I., \& Maryani, L. S. (2020). Hubungan Kompetensi Kepribadian Guru Bahasa Arab dengan Motivasi Belajar Siswa. Lisanul Arab: Journal of Arabic Learning and Teaching, 9(2), 147-155. https://doi.org/10.15294/la.v9i2.37840

Syarifuddin, S. (2014). Total Quality Manajement (TQM) sebagai Manajemen Mutu Alternatif pada Program Studi Pendidikan Bahasa Arab. Al-Ta'rib : Jurnal Ilmiah Program Studi Pendidikan Bahasa Arab IAIN Palangka Raya, 2(1), 21-34. https://doi.org/10.23971/altarib.v2i1.1531

Undang-Undang Nomor 14 Tahun 2005. (n.d.). Retrieved September 7, 2021, from https://jdih.kemenkeu.go.id/fulltext/2005/14tahun2005uu.htm

Zhang, L. (2007). Do personality traits make a difference in teaching styles among Chinese high school teachers? Personality and Individual Differences, 43(4), 669-679. https://doi.org/10.1016/j.paid.2007.01.009

\section{COPYRIGHT NOTICE}

Authors retain copyright and grant the journal right of first publication with the work simultaneously licensed under a Creative Commons Attribution 4.0 International License that allows others to share the work with an acknowledgement of the work's authorship and initial publication in this journal. 
(c) (1) (2)

Jurnal Ilmiah Program Studi Pendidikan Bahasa Arab IAIN Palangka Raya Vol. 9, No. 2 /145-154 Al-Ta'rib | p-ISSN 2354-5887 | e-ISSN 2655-5867 
HALAMAN INI SENGAJA DIKOSONGKAN

Jurnal Ilmiah Program Studi Pendidikan Bahasa Arab IAIN Palangka Raya Vol. 9, No. 2 /145-154 Al-Ta'rib | p-ISSN 2354-5887 | e-ISSN 2655-5867 